\title{
GOYA, EL LENGUAJE ALEGÓRICO Y EL MUNDO CLÁSICO. LA ETAPA DE MADUREZ*
}

\author{
POR \\ ROSA LÓPEZ TORRIJOS \\ Universidad de Alcalá
}

\begin{abstract}
The study is concerned with allegory and mithology in Goya's work. These subjects are not very common in the painter's production and very rarely have attracted the interest of scholars. Following the previous study of Goya's work here is considered the last period of his life when he really breaks down with allegorical tradition of the past.
\end{abstract}

Las dos primeras pinturas de Goya mencionadas específicamente como alegorías las conocemos sólo por la cita que de ellas hace el pintor al extender recibo de su cobro. Se trata de «dos cuadros alegóricos a Zaragoza», valorados en 900 reales, pagados por el Ayuntamiento de la ciudad a Goya en febrero de 1793 .

Como se recordará, esta fecha corresponde al período de la grave enfermedad de Goya, cuando el pintor estaba en casa de Sebastián Martínez, en Cádiz -ciudad donde se debió extender realnente el recibo-. Seguramente las necesidades de la enfermedad y la imposibilidad de trabajo del pintor obligaron a sus amigos y familiares a recurrir a todos los pagos pendientes, con el fin de reunir 1 os fondos necesarios. Por esta razón las obras de Zaragoza debieron haber sido ejecutadas con anterioridad a esta fecha. De ellas no hay más noticias, por lo que desconocemos las imágenes representadas por Goya en estas dos primeras y específicas alegorías.

También por estos años realiza Goya el cuadro de los Cómicos ambulantes, en el que aparece una cartela con las palabras "aleg. men.», interpretado como alegoría menandrea, en alusión a la divisa de la Commedia dell'Arte con referencia a su «padre» griego, aunque Glendinning indica, posiblemente con razón, que debería interpretarse más bien como «alegoría menipea», por ser Menipo más conocido de Goya ${ }^{2}$.

* Para este estudio se ha utilizado en parte el texto de la autora, publicado en sueco: "Goyas förhallande till allegorin och den klassiska världen", Goya, Stockholm, 1994 págs. 31-43 [Catálogo de la Exposición del Museo Nacional de Estocolmo, 1994-95].

1 Franciseo de Goya. Diplomatario, Zaragoza, 1981, pág. 313.

2 Véase "Recuerdos y angustias en las pinturas de Goya, 1793-1794», en Goya, Sevilla, 1992, especialmente págs. 141-144 y nota 20 . 
Un carácter distinto tienen otro grupo de alegorías que Goya realiza años después. Se trata de Los cuatro temperamentos representados en una serie de dibujos conservados en el Museo del Prado.

Representan tres hombres y una mujer situados frente a un espejo o un lienzo, en el que pueden verse no sus imágenes, sino las de un mono, una rana, un gato y una serpiente enroscada en una guadaña, respectivamente.

La serie ha sido estudiada fundamentalmente por Nordström, quien hace notar la correspondencia entre los animales que aparecen en el espejo o en el cuadro y la representación tradicional de los temperamentos: sanguíneo, flemático, colérico y melancólico, respectivamente 3 .

Estos dibujos nos muestran el interés de Goya y su entorno por un tema tratado tradicionalmente como alegoría, pero relacionado con el aspecto interior del hombre, tan importante para comprender su personalidad y abordado en aquellos años por la literatura y la pintura en relación con los tratados de «Fisiognomía». Creemos que en este caso Goya se muestra interesado por un tema que será cada vez más importante en su vida: el conocimiento del lado oscuro del hombre, eso que modernamente será llamado subconsciente y que Goya intuye en los sueños, la locura, las visiones y... las viejas alegorías que el espejo saca a la luz ante el asombrado espectador.

Aunque los retratos de Goya son generalmente sobrios y con atención concentrada en la personalidad del retratado, algunos de ellos tienen elementos alusivos a sus profesiones o aficiones (partituras de música, libros, pinceles, armas) y otros, aunque más raramente, contienen elementos relacionados con la mitología y la alegoría ${ }^{4}$.

Así, por ejemplo, el retrato de Floridablanca estudiado en varias ocasiones bajo este aspecto ${ }^{5}$ (fig.1). Tambien el famoso retrato de Jovellanos, de 1798, quien aparece retratado en actitud "meláncolica» $\mathrm{O}$ "estudiosa» ${ }^{6}$, ante una estatua de Minerva, diosa con la que aparece relacionado Jovellanos igualmente en las obras literarias de Meléndez Valdés (Epistola VIII) y Quintana (Oda que le dedica en sus Poesías).

Conocemos la estrecha relación que unía a Jovellanos y Goya y cómo el primero influyó poderosamente en la formación y carrera del pintor ${ }^{7}$, es por tanto lógico que el retrato -sin duda alguna elegido por Jovellanos- recoja la continua alusión de sus contemporáneos a las actividades del político ilustrado relacionadas con las ciencias y con la técnica y protegidas por la diosa griega.

Precisamente en relación con esto ha sido estudiado recientemente el retrato por Javier González Santos ${ }^{8}$, quien demuestra cómo el escudo en que se apoya Minerva es en realidad un

\footnotetext{
3 Goya, Saturno y la melancolía. Estudio sobre el arte de Goya, Madrid, 1989, págs. 94-115. La edicion española utilizada es de 1989, pero la original es de 1962. De esta correspondencia trató ya López-Rey en "A contribution to the artist's life. Goya and the world around him», GBA, 1945, 2, págs. 129-150, relacionándolo con el tema de la "Fisiognomia» de moda en los círculos ilustrados de la época.

${ }^{4}$ Glendinning trata de los elementos alegóricos en algunos retratos de Goya en Goya. La década de los Caprichos. Retratos 1792-1804, Madrid, 1992, especialmente págs. 86-111.

5 Específicamente por Nordström en 1962, "Goya's State Portrait of the Count of Floridablanca" Konsthistorisk Tidsckrift, págs. 82-94, y por Joh F. Moffitt en 1981, "Francisco Goya, Antonio Palomino, caractère, and the State-Portrait of Count Floridablanca», Konsthistorisk Tidsckrift, págs. 119-135.

${ }^{6}$ En relación con el tema de la melancolía es estudiado este retrato por Nordström (ob. cit., 1984, págs. 161-170). María Pemán, por el contrario, señala como modelo para el retrato de Jovellanos el grabado L'étude incluido en la Iconologie par Figures de Gravelot y Cochin que poseía Sebastián Martínez y que Goya pudo ver mientras convalecía de su enfermedad ("Estampas y libros que vio Goya en casa de Sebastián Martínez», AEA, 1992, págs. 303-320. También puede verse al respecto George Levitine, «Some emblematic sources of Goya», JWCI, 1959, págs. 106-131. Mansbach («Goya's liberal iconography: two images of Jovellanos», JWCI, 1978, págs. 340-344) relaciona la iconografía más bien con la situación política de 1798 y con el inminente cese de Jovellanos.

7 Véase Edith Helman, Jovellanos y Goya, Madrid, 1970.

8 "Jovellanos por Goya. Precisiones históricas e iconográficas sobre dos conocidos retratos», Boletín del Museo de Prado, 1992, págs. 45-56.
} 

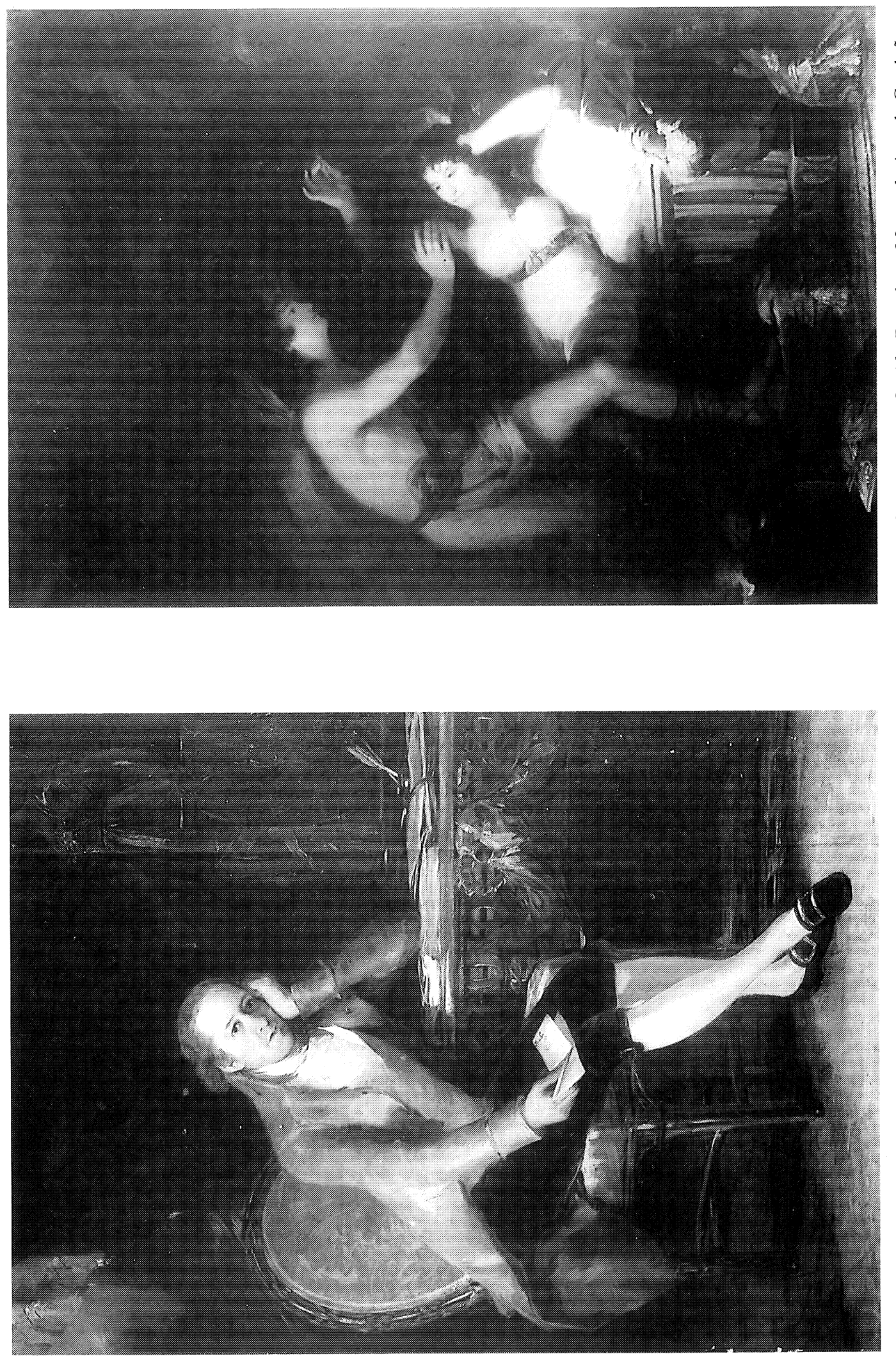

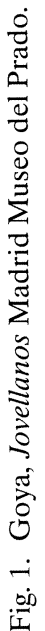


doble escudo con las armas y empresa del Real Instituto Asturiano de Náutica y Mineralogía de Gijón, Instituto fundado por el mismo Jovellanos en 1792 con lo que el cuadro resulta un retrato característico de la Ilustración y la alegoría personificada por Minerva conserva su significado "consagrado por el uso y conocido y comprendido inmediatamente por sus atributos», en palabras de Rejón de Silva, y entra, por tanto, dentro del uso aceptado por el neoclasicismo. En este caso mostraría su relaciónn con Jovellanos a través de las actividades protegidas por la diosa y promovidas ampliamente por el político español, ciertamente una de las personalidades más ilustres de aquel período histórico.

Años después, en 1802, pinta Goya otro retrato alegórico, esta vez de Godoy, hoy perdido, aunque se ha sugerido que fuese el retrato ecuestre subyacente al del duque de Wellington, del mismo tipo, conservado en Londres.

Por documentos publicados por Martínez Ripoll en $1979{ }^{9}$ sabemos que el ayuntamiento de Murcia encargó un retrato del Príncipe de la $\mathrm{Paz}$ "con todas aquellas alegorías que son propias de los distinguidos méritos de dicho Señor Excelentísimo", que fue pintado por Goya y colocado en la sala capitular del consistorio murciano en 1802. De allí fue retirado poco después del motín de Aranjuez y enviado a Madrid, donde se pierde su pista ${ }^{10}$.

Tenemos pues aquí un nuevo retrato alegórico que, lógicamente, al haber desaparecido sin que se conozca reproducción del mismo, no nos es posible comentar ${ }^{11}$.

El propio Godoy precisamente encargó a Goya un grupo de alegorías que fueron pintadas en torno a 1800 .

Son las representaciones de la Agricultura (fig.3), el Comercio, la Industria y la Ciencia y corresponden a cuatro tondos pintados para el palacio de Godoy en Madrid ${ }^{12}$. De ellas conservamos las tres primeras y un boceto de la segunda, mientras que la Ciencia ha sido talmente rehecha que se considera actualmente obra ajena a Goya.

Estas pinturas fueron estudiadas por Nordström, y él indica la inspiración parcial en Ripa para la Agricultura (arado, corona de espigas, presencia del zodiaco y árbol) ${ }^{13}$ y el Comercio (cigúeña). Dos de estas alegorías. Agricultura y Comercio, fueron representadas también por Francisco Bayeu hacia $1770{ }^{14}$ y por Maella en la Apoteosis de Adriano en el Palacio Real de Madrid, en 1797. En esta última obra aparece la Agricultura como joven con azada y hoz en las manos y aperos de cultivo a su alrededor, es decir, coincidente con lo indicado por Ripa, y el Comercio

9 "Un retrato alegórico de Godoy, por Goya», Goya, 1979, núm. 148-150, págs. 294-299. Remitimos a este trabajo para datos sobre documentación, ejecución y pérdida de la obra, así como sugerencias sobre su posible paradero.

10 Glendinning (ob. cit., 1992) trata de otros retratos de Godoy con elementos significativos y en relación con un retrato grabado del Príncipe de la Paz, cita la presencia de una cabeza de Jano junto a él, significando la previsión y cautela de Godoy (pág. 90). Como el mismo autor indica, la cabeza de Jano se incorporó al escudo de Godoy cuando se le hizo Príncipe de la Paz, por lo que habría que considerarlo más bien en relación con el título recién recihido, ya que, como es sabido, Jano era personaje relacionado con la guerra y la paz, pues las puertas de su templo de Roma se abrían o cerraban según hubiese guerra o paz. Jano, por tanto, podría figurar entre las alegorías citadas en este retrato goyesco y representar, respecto a Godoy, lo que Minerva respecto a Jovellanos.

11 El tema de los elementos alegóricos en el retrato es naturalmente uno de los más atractivos y necesitados de estudio, pero también, como ocurre frecuentemente en el campo iconológico en general, se pueden establecer relaciones y deducciones difíciles de probar y costosas de admitir. Un ejemplo de ello en relación con Goya es, en nuestra opinión, el estudio de William L. Pressly, "Goya's Don Manuel Osorio de Zúniga. A Christological allegory», Apollo, 1992, págs. 1220 .

12 José Gudiol, Goya 1746-1828. Biografía, estudio analítico y catálogo de sus pinturas, Barcelona, 1980, págs. 437440 .

13 Ob. cit., págs. 116-123. También indica su similitud con el Ceres y Pan de Rubens en el Palacio Real de Madrid.

14 Se conservan, al parecer, dos bocetos en Zaragoza, citados por José Luis Morales (Los Bayeu, Zaragoza, 1979, pág. 58, núm. 19), pero cuya ambigua descripción: «bellas matronas con atributos tradicionales" y la ausencia de reproducción no nos permite establecer ningún tipo de relación ni con Ripa ni con Goya. 
«mediante unos hombres contratando ciertas mercaderías» ${ }^{15}$. Como puede verse, los hombres intercambiando mercancías son comunes a Maella y Goya aunque la interpretación de ambos grupos es muy distinta. Fabre, al hacer la descripción de estas pinturas no indica la fuente, que pudo ser común a Goya.

En cuanto a la Ciencia, al considerarse totalmente rehecha y no conocerse fotografías de la primitiva, se señala únicamente la falta de relación con Ripa, de la imagen conservada.

Más recientemente, Isadora Rose 16 estudia también estas alegorías, y basándose en el conocimiento de antiguas fotografías y decoraciones «in situ», y observando la disposición del antiguo palacio de Godoy, concluye que debieron corresponder a la antecámara de Godoy ${ }^{17}$ y pospone la fecha de ejecución a 1801-1802, indicando igualmente que si la imagen conocida de la Ciencia se corresponde iconográficamente con la original de Goya, ésta también estaría basada en Ripa pero en la edición de Hertel de 1758-60 ${ }^{18}$.

Nordström, siguiendo a Gudiol, considera hecha para el mismo palacio de Godoy la Alegoría de la Poesía (fig. 4) del museo de Estocolmo, ubicación dudosa, con los datos que poseemos actualmente ${ }^{19}$, pero, próxima en fecha, y a efectos iconográficos puede relacionarse con las mencionadas anteriormente, en cuanto es otra de las pinturas goyescas que siguen más de cerea las indicaciones de Ripa. En la Poesía, la figura central y los tres amorcillos con instrumentos musicales que la acompañan corresponden bastante bien a la descripción que hace Ripa, según indicó Soria ${ }^{20}$. Además Goya añade el Parnaso con Pegaso y las musas, -que pudo ver igualmente en una ilustración de Gravelot y Cochin para la edición de 1791 de la Iconología ${ }^{21}$-, una fuente a la derecha que debe ser Castalia y no Hipocrene, si se trata del monte Parnaso, y una representación de poetas.

La poesía había sido representada también en el Palacio Real por Bayeu en uno de los óvalos del techo con la Apoteosis de Hércules (1768-69) 22 y en Apolo protegiendo las Ciencias de $1786^{23}$, también por Mengs en la Apoteosis de Trajano 1774-1776 ${ }^{24}$.

15 Véase Francisco José Fabre, Descripción de las alegorías pintadas en las bóvedas del Real Palacio de Madrid, Madrid, 1829 págs. 82-83. Puede verse reproducida en El Palacio Real de Madrid, Madrid, 1975, pág. 103.

16 "Goya's allegories and the sphinxes: "Commerce", "Agriculture", "Industry", and "Science" in situ", Burlington Magazine, 1984, I, págs. 34-39.

17 Recuérdese que primero se pensaron hechas para la biblioteca de Godoy donde estaban cuando el edificio dejó de pertenecer a Godoy, Beruete indicó que pertenecían a la antecámara del valido y Gudiol las adscribió a la escalera del palacio, lo que se ha venido manteniendo hasta ahora.

18 ob. cit., pág. 38. Respecto a la nueva datación de las obras, ésta explicaría que no estuvieran hechas en 1800, cuando González de Sepúlveda visitó por primera vez el palacio, indicando solamente que «Los techos son cosa muy desgraciada" (Enrique Pardo Canalís, "Una visita a la galería del Príncipe de la Paz», Goya, 1979, pág. 301), mientras que en la visita realizada en 1807 indica: "pero los techos son pintados de Goya y un discípulo suyo» (Isadora Rose, "La segunda visita de González de Sepúlveda a la colección de Manuel Godoy", AEA, 1987, pág. 137).

19 Recuérdese que esta pintura no se menciona en las visitas de González de Sepúlveda al palacio de Godoy (ver nota anterior). La primera mención que se hace de ella es la de Yriarte en 1867, quien la cita en la colección del cónsul austriaco en Cádiz. Soria pensó que esta pintura había sido hecha para la duquesa de Alba, permaneciendo en su casa de Sanlúcar, lo que explicaría su presencia posterior en Andalucía. Sobre esto volveremos más adelante.

20 "Goya's Allegories of Fact and Fiction", BM, 1948, págs. 196-200, y Nordström, ob. cit., págs. 125-126. Sin embargo, Ripa indica que los tres niños alados deberán presentar respectivamente la lira y el plectro, la flauta de pan (siringa) y la trompa mientras en la pintura de Goya aparecen llevando la flauta recta, los címbalos y la trompa, en tanto que la lira aparece a los pies de la Poesía.

21 Sayre, "Goya, un momento en el tiempo", en Goya y la constitución de 1812, Madrid, 1982, págs. 60-61. En nota 23 indica la autora cómo las láminas aparecen antes en el Almanach iconologique, ou des arts, los años 1765-1781.

22 Fabre, ob. cit., pág. 53. Los bocetos fueron expuestos en Goya joven (1746-1776) y su entorno, Zaragoza, 1986, pág. 104, n. 54 , aunque la versión es distinta a la de Goya.

23 Morales, ob. cit., 1979 pág. 106, n. 149.

${ }^{24}$ Fabre, ob. cit., pág. 145. 


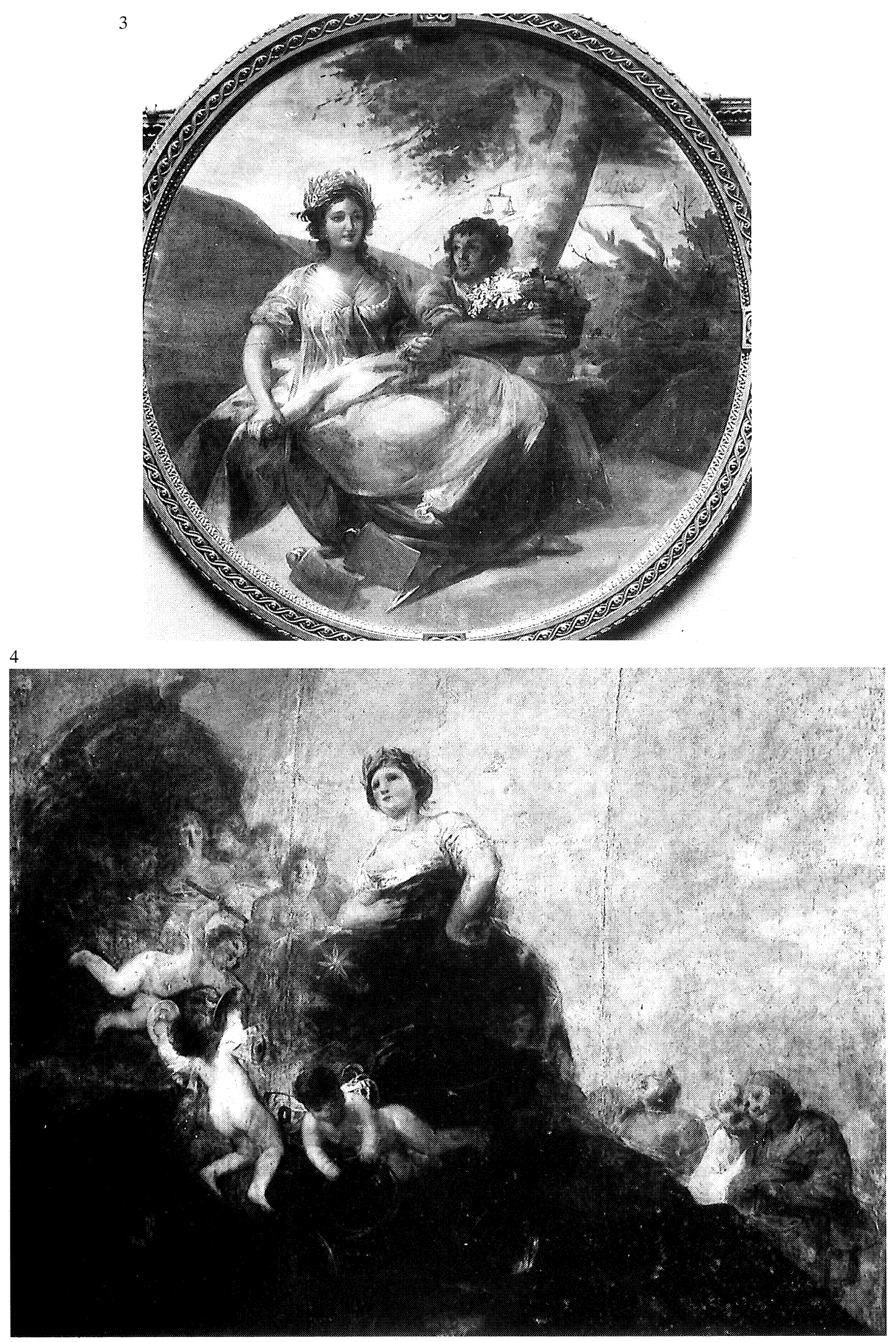

Fig. 3. Goya, La Agricultura. Madrid. Museo del Prado.

Fig. 4. Goya, Alegoría de la Poesía. Estocolmo. National Museum. 
Creemos que estas alegorías sirven muy bien para mostrar la relación de Goya con el tema. Cuando el pintor recibe un encargo de este tipo, lejano a sus intereses vitales y personales y por tanto poco estimulante para su imaginación y dedicación, Goya recurre a la "codificación» más fácil y habitual, la Iconología de Ripa, a la que se ciñe con bastante fidelidad cuando el tema es más intelectual y abstracto - caso de la poesía- y más libremente cuando el tema permite la concreción en actividades cotidianas y populares, así en el caso de la Agricultura (para el que toma ciertos elementos de Ripa, como la corona de espigas, el azadón, arado, la presencia del zodiaco y de un árbol, que luego combina caprichosamente) y del Comercio (para el que sólo toma la cigüeña, que además no aparece en el boceto). Para la Industria, sin embargo, elige la actividad manual sin referencia alguna al manual italiano.

Para Godoy fue pintada por esos años también la célebre Maja desnuda (fig. 5), citada a veces como Venus, aunque en realidad nadie creyese que fuera un cuadro mitológico y solamente por conveniencias fuese llamado así.

El lienzo fue visto en 1800 en el palacio de Godoy, en un «gabinete interior» del Príncipe de la Paz, donde estaba «en compañía de varias Venus» como la de Velázquez, regalo de la duquesa de Alba 25.

El hecho de que estuviera en el "gabinete interior», de que formase parte de un grupo de desnudos femeninos perseguidos por la Inquisición - como veremos más tarde- y de que fuese retrato íntimo sin duda alguna, podría hacernos pensar gue la Maja era obra realmente secreta y poco accesible al conocimiento general. Por ello sorprende grandemente el hecho de que las $\mathrm{Ve}$ nus de Goya -en plural y aludiendo por tanto también a la Maja vestida que se le unió poco después-aparezcan citadas en la prensa española en 1811.

La cita se debe a González Azaola, quien dice al respecto: «Todos los amantes de las bellas artes tienen sin duda noticia de nuestro célebre pintor D. Francisco de Goya y Lucientes, y muchos abrán admirado sus bellos techos al fresco, sus Venus y sus retratos», texto correspondiente al Semanario Pintoreseo de Cádiz del día 27 de marzo de $181{ }^{26}$.

También son citadas las Majas como Venus por el propio hijo de Goya en 1831, al relacionar las obras famosas de su padre: «... las Venus que tenía el Príncipe de la Paz» ${ }^{27}$.

Solamente la inquisición, en 1815 , les da el título que realmente responde a la imagen pintada. Así, el escrito del Director General de Secuestro al Inquisidor Fiscal del Santo Oficio habla de «... la Venus dornida con marco dorado... es copia de Tiziano, el que representa una mujer desnuda sobre una cama... es su autor Don Francisco Goya; la mujer vestida de maja sobre una cama es también del citado Goya» ${ }^{28}$ y el Inquisidor Fiscal al solicitar la presencia de Goya, el 16 de marzo de 1815 dice: «resultando ser Don Francisco de Goya el autor de dos de las pinturas que se han recogido de dicho almacén [Casa de los Cristales, antigua presidencia del Consejo de Ministros], una de ellas que representa una mujer desnuda sobre una cama... y la otra una mujer vestida de maja sobre una cama, es de dictamen que se mande comparecer en este Tribunal a dicho Goya para que las reconozca y declare si son obra suya, con qué motivo las hizo, por encargo de quién y qué fines se propuso» ${ }^{29}$.

25 Pardo Canalís, ob. cit., La visita fue realizada, entre otros, por Ceán, y su noticia esta extraída de las notas de los Diarios de González de Sepúlveda.

26 Apud Glendinning, Goya y sus críticos, Madrid, 1982, pág. 74. La cita continúa: "mas no todos conocen su obra maestra de dibuxo y gravado, o sus famosas estampas satíricas que corren con el nombre de Caprichos de Goyan. Esto demuestra un conocimiento de las obras "sospechosas" de Goya mucho mayor del supuesto y explican, por tanto, las precauciones que el pintor hubo de tomar en fechas posteriores. Naturalmente, el texto se publica en un lugar y en una fecha en que se consideran definitivamente superados el absolutismo y la inquisición.

27 Francisco de Goya. Diplomatario, ob. cit., pág. 518.

28 Ibidem, pág. 431.

29 Ibidem. Como es sabido, la citación afortunadamente no tuvo repercusiones para Goya, seguramente por intervención de amigos protectores (Pierre Gassier, Goya. Temoin de son temps, Fribourg, 1983, pág. 232). 
Así pues, vemos cómo el título mitológico sólo es empleado para disimular el «realismo» de una obra ciertamente «atrevida» para su época.

En este contexto creemos que hay que situar el cuadro de Psique y Cupido (fig. 2), realizado hacia 1800 y que es una obra mitológica de carácter más riguroso.

Al tratar de esta obra siempre se subrayan las características neoclásicas en el aspecto formal y su técnica más prieta que otras obras contemporáneas. Igualmente es notorio, a primera vista, el parecido que tiene la Psique con la maja pintada por esos mismos años, y quizás en ello esté la clave de esta mitología que ciertamente se hizo con intenciones muy determinadas, hoy por hoy difíciles de precisar, mientras no sepamos quién fue realmente la modelo de ambos cuadros y para quién fue hecha la Psique.

Se ha supuesto que el cuadro fuera hecho realmente por el pintor para sí mismo, estableciendo así una alegoría personal o biográfica ${ }^{30}$. Nosotros opinamos que habría que dirigir la atención más bien hacia el entorno del cliente de la "maja" que poseía ese gabinete interior donde se mostraban y ocultaban a la vez mitologías y desnudos femeninos como tema común y en cuyo contexto la Psique y Cupido de Goya representaría una especie de retrato mitológico, cuyo significado constituye ciertamente un tema muy atractivo para la investigación. Por otra parte, Godoy, por lo que sabemos, era una de las pocas personas que podían permitirse "gabinetes íntimos» con imágenes y alusiones como las que sugieren estas obras ${ }^{31}$.

El cuadro, en nuestra opinión, debió ser un encargo preciso, con indicaciones específicas y en él se observan ciertas rigideces que tal vez puedan explicarse por un requerimiento muy detallado del cliente. Las características de mayor aproximación al neoclasicismo que se señalan habitualmente en esta obra indicarían tal vez esa aceptación por parte del pintor, de una elección y un criterio ajeno, y explicarían esa falta de espontaneidad que aparece en Goya "cuando los temas se le imponen o no van bien a su temperamento", en palabras de Lafuente Ferrari ${ }^{32}$.

Un personaje conocido y quizás el retrato alegórico más representativo de los efectuados por Goya es el de la marquesa de Santa Cruz (fig. 6), de 1805, citado como Euterpe por Ezquerra.

La relación con la musa se debe al tocado vegetal de la marquesa y a la lira que sostiene en sus manos. Sin duda estos atributos fueron seleccionados por la propia retratada para darle una

30 Así opina Buendía en Colección Cambó, Madrid, 1990, págs. 392-401, núm. 43. Recientemente Alcalá Flecha ha señalado como posible fuente iconográfica para esta pintura una de las ilustraciones de las Metamorfosis de Ovidio, en edición francesa de París, 1768, y española de Madrid, 1805 («Nuevas fuentes compositivas de la obra de Goya», Boletín del Museo del Prado, 1991, págs. 63-70). El grabado original sería obra de Massard y el que realizó las planchas para la edición española fue José Assensio y Torres.

31 Recuérdese que en el gabinete de Godoy estaba la Maja desnuda y también la Venus del espejo de Velázquez, por cierto con posturas corporales opuestas, muy apropiadas para hacer "pendant». Recuérdese también que el cuadro de Velázquez fue regalo de la duquesa de Alba y la Maja se ha sugerido que pudiera ser el retrato de otra amante de Godoy: Pepita Tudó (Gassier, ob. cit., págs. 144-145); obras y situaciones llenas de sugerencias que aún podría completar la Psique y Cupido.

Ciertamente, el cuadro mitológico no aparece citado en la visita realizada a la colección de Godoy en 1800 (Pardo Canalis, ob. cit.) ni tampoco en la de 1807 (Isadora Rose, «La segunda visita de González de Sepúlveda a la colección de Manuel Godoy", $A E A, 1987$, págs. 137-152), pero dadas las coincidencias en fecha y parecidos eon la Maja, debería investigarse por este entorno.

Por otro lado, y en relación con el lecho sobre el que reposa Psique, y a cuyos adornos ha prestado tanta atención Buendía en su estudio, podemos recordar que Godoy tenía un mobiliario riquísimo y que, dentro de él, llamaba la atención la cama, que «es de lo mejor que se ha trabajado en España particularmente en bronces dorados muy bien hechos creo son de Ferroni», según indica González de Sepúlveda en su visita de 1800. Isadora Rose (ob. cit., pág. 142) recuerda también la referencia que hace George Sand en su autobiografía al lujoso mobiliario de Godoy, «a base de camas ornamentadas, sillones y sofás tapizados en tonos rojo intenso y oro brillante».

32 Antecedentes, coincidencias e influencias del arte de Goya..., ed. Madrid, 1987, pág. 104. 


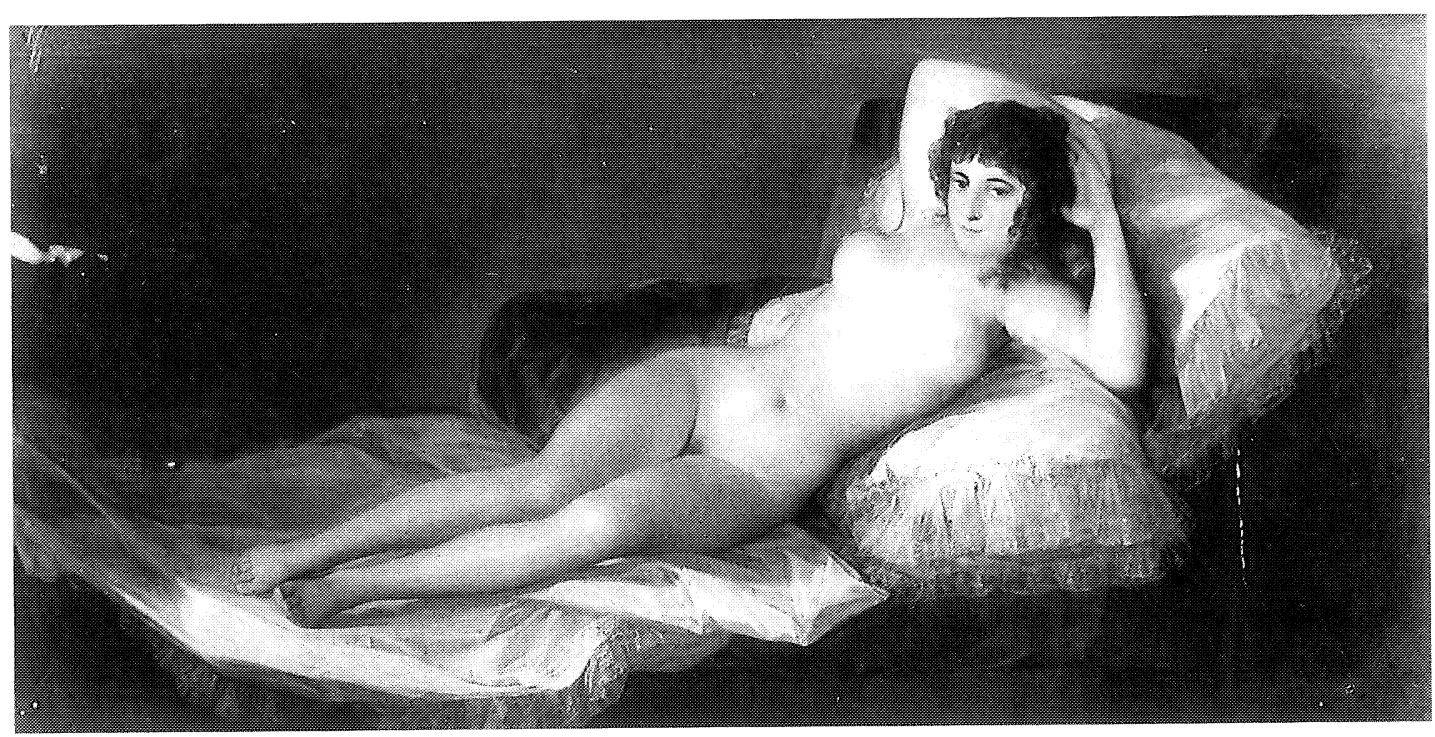

Fig. 5. Goya, Maja Desnuda.

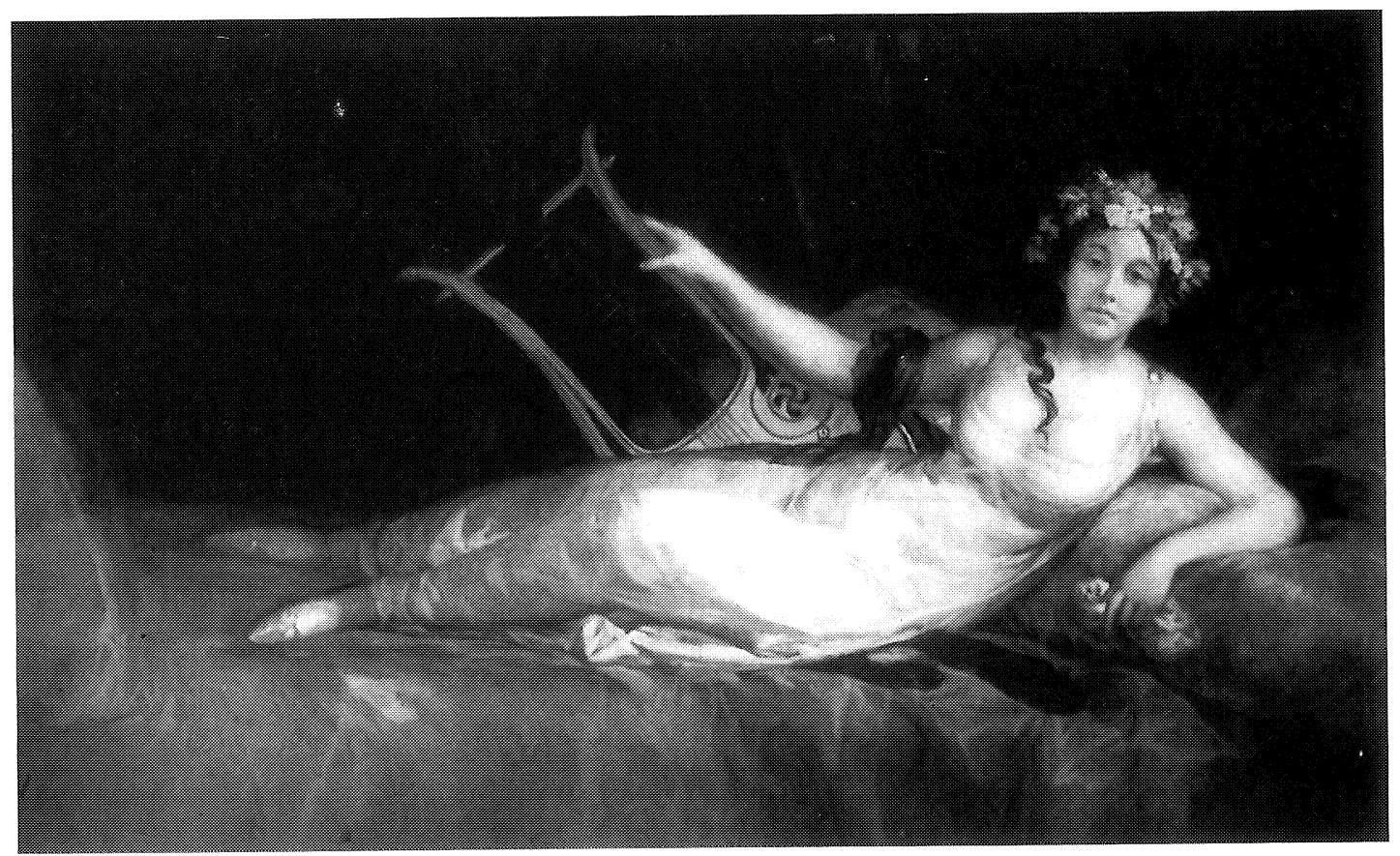

Fig. 6. Goya, La Marquesa de Santa Cruz. Madrid. Museo del Prado. 
referencia alegórica a una afición, a un hecho o a un momento concreto, que hoy, con los datos que tenemos, se nos escapa ${ }^{33}$.

Hacia 1808 realiza Goya el cuadro del Coloso, en el que aparece la figura de un gigante, personaje mitológico que no creemos tenga nada que ver con la intención del pintor al realizar esta obra.

El cuadro estaba en la colección particular de Goya en $1812{ }^{34}$ y ha recibido múltiples interpretaciones que ven el cuadro en general como alegoría de la guerra, o de la humanidad, y la figura del coloso en conexión con representaciones contemporáneas de Napoleón como gigante ${ }^{35}$, y también como genio protector de España que se levantaba contra los franceses, según la Profecía del Pirineo de Arriaza ${ }^{36}$.

En este sentido tenemos aquí quizás el inicio de la ruptura con el lenguaje alegórico del pasado, al representar Goya una realidad histórica contemporánea expresada por una imagen simbólica inspirada en fuentes contemporáneas y fácilmente asequible a la comprensión general. Esta sería realmente una expresión del nuevo lenguaje alegórico.

Quizás por los mismos años del Coloso realizase Goya los «quatro [cuadros] de las Artes» que poseía en 1819 y que se inventarían con el número 27.

Estas cuatro alegorías son desconocidas para nosotros por ahora. Si bien por la tasación -80 reales para las cuatro- podría pensarse en bocetos, no debe ser así realmente, ya que en la misma relación se distinguen expresamente bocetos y pinturas y las Artes se mencionan entre las segundas.

Pero llegamos, en 1810, a la realización de uno de los cuadros alegóricos más importantes y famosos de Goya por muchos motivos. Generalmente conocido como Alegoría de Madrid (fig. 7), fue encargado en realidad como retrato del rey José I, retrato gue Goya transformó, reduciendo la imagen real y envolviéndola en una gran alegoría, que la historia se encargó de conservar como tal, haciendo desaparecer el retrato y cumpliendo así seguramente el deseo inicial del pintor.

La obra le fue confiada a Goya en 1810 por recomendación de Tadeo Bravo de Rivero, a quien el Ayuntamiento de Madrid había encargado de buscar pintor para el retrato real ${ }^{37}$.

Años antes, en 1806, Goya había retratado a Bravo de Rivero y en 1808 había dirigido el trabajo de Asensió Juliá para la decoración de la fachada de la casa de don Tadeo, con motivo de la proclamación de Fernando VII. La decoración consistió, entre otras cosas y según la Gace$t a$, en una representación de la "fidelidad limeña ${ }^{38}$, la que en un medallón tenía el retrato del

33 En su propio entorno se perdió pronto este conocimiento, dado que la obra se relaciona en los inventarios de la familia como una musa y en épocas más recientes como el retrato "de la abuela en camisa". La afición que se nos ha transmitido de la marquesa es "la asistencia a las gradas, donde los aficionados se sienten al alcance de los toreros». La puesta al día sobre la historia de esta obra podemos verla en "El retrato de ]a marquesa de Santa Cruz en el Prado", publicado en las "Noticias del Prado", Boletín del Museo del Prado, 1986, enero-abril, págs. 61-66. Reeuérdese también que Yriarte en su Goya... (París, 1867) cita en la colección del marqués de Santa Cruz en Madrid «Une Dame en costume de fantaisie», con medidas muy próximas a las de Euterpe (pág. 134).

34 F. J. Sánchez Cantón, "Cómo vivía Goya", $A E A$, 1946, pág. 106.

35 Valeriano Bozal, «El Coloso de Goya», Goya, 1985, págs. 289-245.

36 Glendinning, "Goya and Arriaza's Profecía del Pirineo», JWCI, 1963, págs. 363-366. El mismo autor en Goya y sus críticos, Madrid, 1982, habla de una imagen parecida que Taylor describe en su Voyage pittoresque en España, como vista en la Galería Española del Louvre. Se trata de un boceto que muestra la invasión napoleónica de España como «una gran águila [que] se cierne sobre los Pirineos, haciendo sombra con sus alas extendidas sobre toda la Península y sus gentes huyen despavoridas ante ella... una de las composiciones más grandes y sublimes gue jamás se haya concebido en la historia de la pintura" (pág. 90). Recuérdese que existe también un aguatinta que representa una figura gigantesca sentada y dos dibujos que la representan dormida y con personajes trepando sobre él, imágenes que se han puesto en relación con la emblemática española (José Manuel B. López Vázquez, "Goya, los gigantes y los emblemas», Goya, 1985, págs. 102112).

37 Pérez y González, apud Goya y la constitución de 1812, ob. cit., pág. 86.

38 Don Tadeo provenía de Lima. Breves noticias biográficas de él da Glendinnig en "Goya's Patrons», Apollo, 1981, pág. 246. 

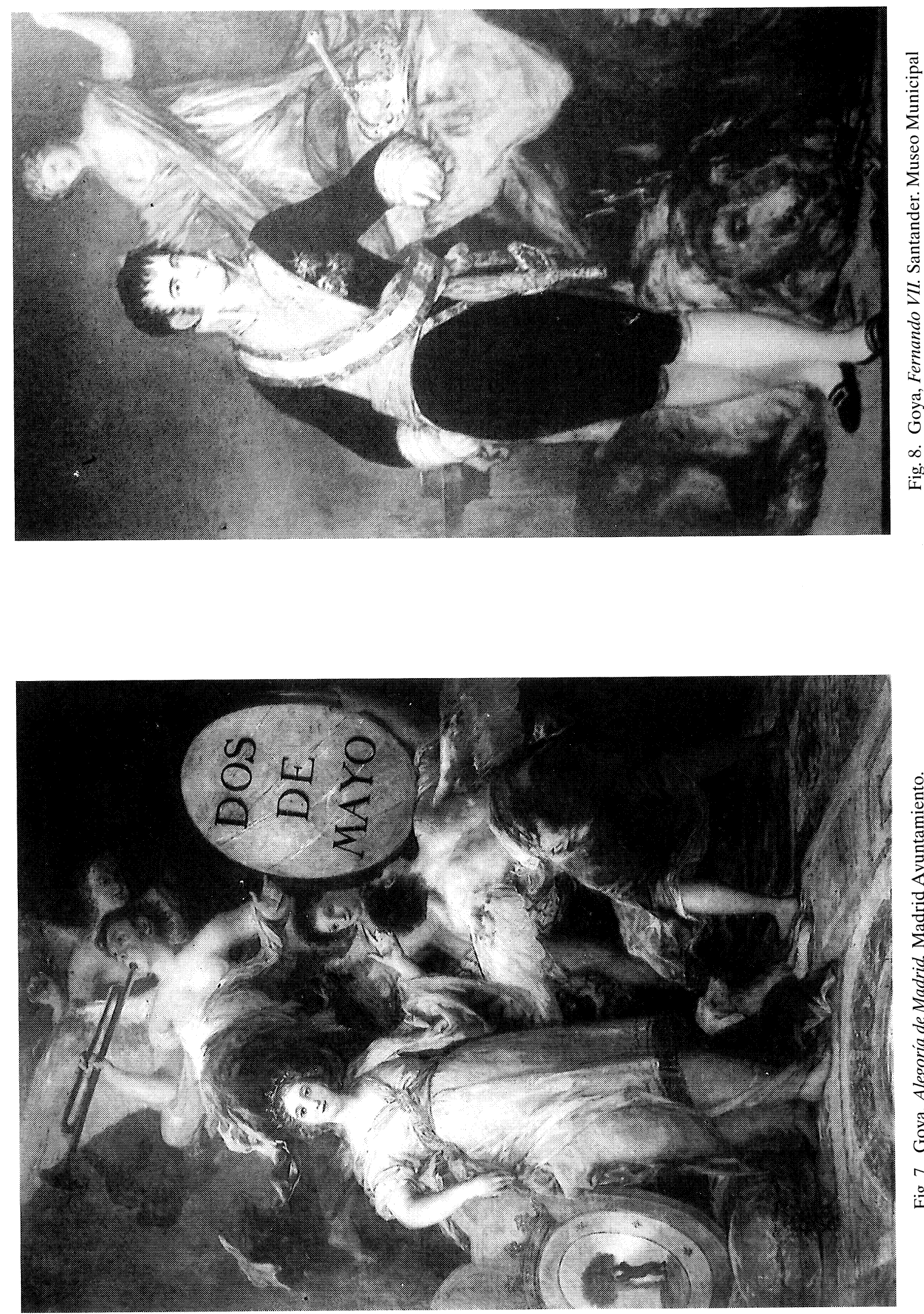

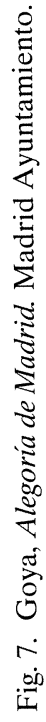


rey» y fue realizada bajo la dirección de D. Francisco Goya ${ }^{39}$, reforzando así una relación que después sirvió para encargar el retrato de José I a nuestro artista y que, por lo que se ve, mantuvo el modelo de la decoración dedicada en 1808 a Fernando VII, es deeir, una figura femenina alegórica (de la Fidelidad o de Madrid) y un retrato del rey (Fernando VII o José I), lo que hace suponer el éxito de la fórmula empleada en 1808 , bien por sugerencia del propio D. Tadeo, bien por indicacion de Goya que satisfizo al cliente.

Por las manifestaciones del propio intermediario parece que en el caso de la Alegoría de Madrid, la ausencia del rey (es decir, la imposibilidad de retratarlo del natural) y el contar sólo con una estampa de medio perfil grabada en Roma, como única imagen de José I, determinaron a Goya a componer la gran alegoría.

No obstante, se puede recordar que el pintor, retratista por excelencia, rechazó -salvo casos muy excepcionales que estamos revisando ahora- la realización de alegorías ${ }^{40}$, por lo que debió encontrarse muy comprometido para realizar tal obra y muy a disgusto con ella para volcarse en la alegoría y relegar el retrato.

El esquema compositivo de figuras alegóricas presentando un pequeño óvalo con el retrato de un personaje era habitual en el arte del siglo xviII y, por citar algunos ejemplos españoles del entorno de Goya, había sido hecho por Antonio González Ruiz en el cuadro de la Fundación de la Academia de San Fernando, en 1745, donde aparecen los retratos de Felipe V en el paño ondulante de la trompeta de la Fama, en la parte superior de la obra, y del marqués de Villarias -ministro de Estado y protector de la Junta preparatoria de la Academia- en un óvalo -por cierto con bastante parecido al de Goya- sostenido por dos amorcillos en la parte inferior. Esta obra sin duda alguna muy vista por Goya, ya que se colocó en la Academia. También fue hecho por José del Castillo, en 1775, en su alegoría de Carlos III y la monarquía española.

Así pues, podemos decir que Goya seleccionó en este cuadro dos de los temas más alejados de su producción habitual y por supuesto, de su gusto e «inclinación»: el retrato en madallón y las grandes alegorías, lo que para nosotros puede explicarse por un deseo expreso del pintor de «diluir» la imagen del rey francés presentándola a pequeño tamaño y rodeada de grandes figuras alegóricas que constituyen el objeto principal de atención del cuadro, o por una imposición del gusto de Don Tadeo. Sin embargo, el cuadro no debió convencer al Ayuntamiento, ya que colocó después en la sala capitular no el retrato de Goya, sino uno de cuerpo entero, como era habitual ${ }^{41}$.

La situación de compromiso que el encargo supuso para Goya explicaría, en nuestra opinión, la combinación de dos temas tan poco gratos a Goya y también que posteriormente se desentendiera de los sucesivos "retoques» que hubo de sufrir el espacio destinado al retrato real, pasando el trabajo a sus ayudantes Felipe Abas y Dionisio Gómez ${ }^{42}$.

Goya, como hemos dicho anteriormente, envuelve el retrato del rey francés en una serie de figuras alegóricas a gran escala, de fácil lenguaje e interpretación: mujer con corona y escudo de la ciudad y perro a sus pies, representación de la fiel y coronada villa de Madrid, ángeles o genios sosteniendo el retrato real y genios alados con trompeta y con corona de laurel y olivo representando la Fama y la Victoria, respectivamente, en imágenes consagradas desde el mundo clásico y recogidas naturalmente por Ripa en su celebrada Iconología.

39 Apud Lafuente, ob. cit., 1987, pág. 153.

40 De hecho no realizó tampoco la decoración de la casa de Bravo de Rivero, sino que solamente la dirigió.

41 Goya y la constitución de 1812, ob. cit., núm. 3.

42 Francisco de Goya. Diplomatario, ob. cit., doc. 237 y 238, págs. 367-368. Como es sabido, las rectificaciones fueron numerosas. Se puso la palabra constitución en 1812, la imagen del rey José de nuevo en diciembre del mismo año, «constitución" en junio de 1813, la imagen de Fernando VII en 1814, el libro de la constitución en 1843 y las palabras "Dos de mayo" en 1872. Es decir, el espacio oval fue destinado tanto al rey francés como a la fecha del comienzo de la lucha contra él y tanto a la constitución española como a la imagen de su mayor detractor. 
Nos parece muy importante retener la imagen de esta Alegoría de Madrid para revisar el segundo gran cuadro alegórico de Goya, interpretado generalmente como España, Tiempo e Historia (fig. 9).

Éste consta sólo de tres figuras: Tiempo e Historia, fácilmente identificables con el lenguaje alegórico tradicional, y una figura femenina protagonista sin duda alguna, e interpretada como España, la Filosofía o la Constitución ${ }^{43}$.

La primera interpretación es la más antigua pues proviene de Yriarte, en su Goya de 1867, el autor la cita como L'Espagne écrivant son histoire y Viñaza traduce el título cuando la menciona en su Goya de $1887^{44}$. La última interpretación interesa grandemente para el tema que da título a este estudio y explica la actitud positiva e implicada del pintor hacia esta obra.

Como se recordará, existen además dos dibujos y un boceto en relación con este tema y tenidos en cuenta para el gran lienzo del Museo de Estocolmo.

Sayre, al iniciar su estudio, parte de la tradicional relación entre el Tiempo y la Historia, y el Tiempo y la Verdad, citando ejemplos en grabados de 1696 y $1713{ }^{45}$, y pasa revista a dos dibujos de Goya (Prado), La Verdad y el Tiempo y La Verdad desnuda, muy próximo este último a la figura del boceto del museo de Boston (La Verdad descubierta por el Tiempo ante la Historia como testigo) (fig. 10), que aparece disipando la oscuridad representada por las aves nocturnas que aparecen en la parte superior. Después se fija en la pintura definitiva de Estocolmo, cuyas figuras habían sido identificadas por Soria a partir de Ripa y rechaza la relación de esta pintura de Goya con la Alegoría de la Poesía del Museo de Estocolmo, como había sido propuesto por Nordström principalmente.

Finalmente, analizando independientemente los distintos elementos del cuadro de Goya: luz, reloj de arena, cetro, vestido y libro, y relacionándolos con otros dibujos del propio pintor y con las distintas constituciones españolas de la época, propone el título de Adopción de la Constitución de 1812 por España.Es decir, se trataría de una alegoría de la constitución española en la que se resalta su bondad, luz, verdad y libertad, y la importancia del momento histórico de su adopción.

Si esto es así, y nosotros creemos muy razonables y fundados los argumentos de Sayre para este análisis, conviene ahora considerar qué postura tomó Goya ante esta alegoría.

Como vemos, el cuadro consta de tres personajes, dos de los cuales, Tiempo e Historia, siguen una iconografía consagrada desde tiempos clásicos y divulgada a partir de los tipos, fórmulas y modelos de Ripa, que nuestro pintor había utilizado ya con anterioridad. Goya los aprovecha simplificando al máximo su apariencia y atributos, es decir, adoptando un lenguaje claro y •sencillo, como reconendaban los neoclásicos ${ }^{46}$. El tercer personaje es, en realidad, una alegoría

43 Soria, Nordström y Sayre, ob. cit.

44 Sánchez Cantón en su estudio de este cuadro (“La elaboración de un cuadro de Goya», AEA, 1945, págs. 301307) lo interpreta como España ante la Historia, que escribe sus fastos, mientras el Tiempo, que no puede detenerse, la invita a seguirle.

45 A este respecto hay que recordar que ambos temas se representan en pintura en Madrid por contemporáneos de Goya; así, por ejemplo, El Tiempo descubriendo la verdad de A. de la Calleja, director de la Academia de San Fernando de 1778 a 1785, imagen dentro de la más pura tradición del barroco del xvII. El mismo tema aparece pintado en el techo de la sala de Consejos del Palacio Real pintado por Maella en torno a 1764-1770; por tanto, cuando Goya estaba en Madrid. Del mismo modo existen numerosos ejemplos anteriores sobre el tema de la historia y el tiempo que Goya pudo conocer, tales como el relieve de Fernando VI, hecho por Felipe de Castro, la versión en tabla del fresco de la Historia escribiendo sobre el Tiempo, de Mengs, en el museo Clementino, que el pintor dejó en Madrid. En el Palacio Real existían igualmente una serie de obras de este tema como el techo pintado por Maella en 1764, el mismo grupo en el techo de las Ordenes de la Monarquía Española, de Bayeu, de 1794, y la Apoteosis de Adriano, de Maella, de 1797. Todas anteriores o contemporáneas a la obra de Goya.

46 Sobre este aspecto véase Rosa López Torrijos «G̃oya, el lenguaje alegórico y el mundo clásico. Sus primeras obras», $A E A, 1995$, págs. $165-177$. 


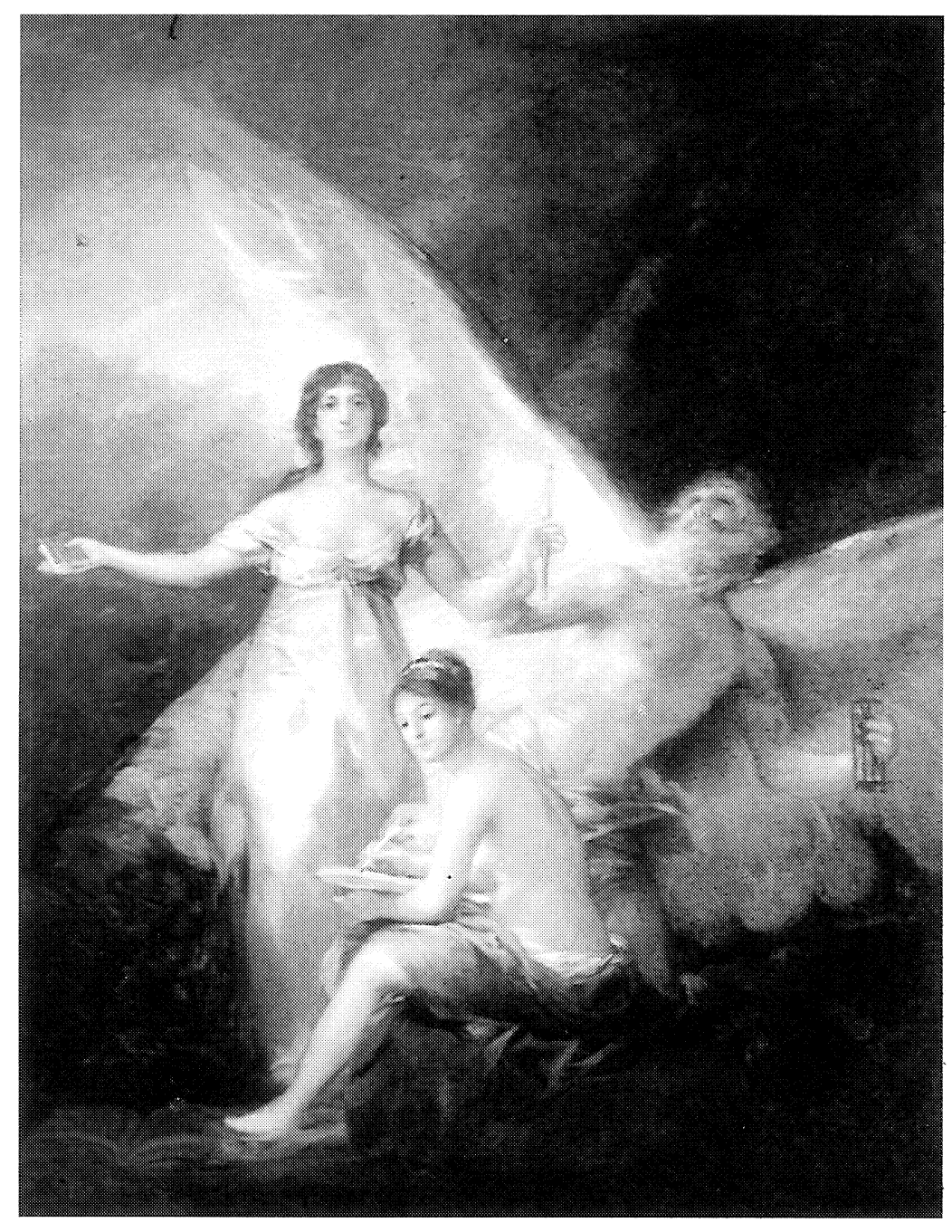

Fig. 9. Goya, España Constitucional. Estocolmo. National Museum.

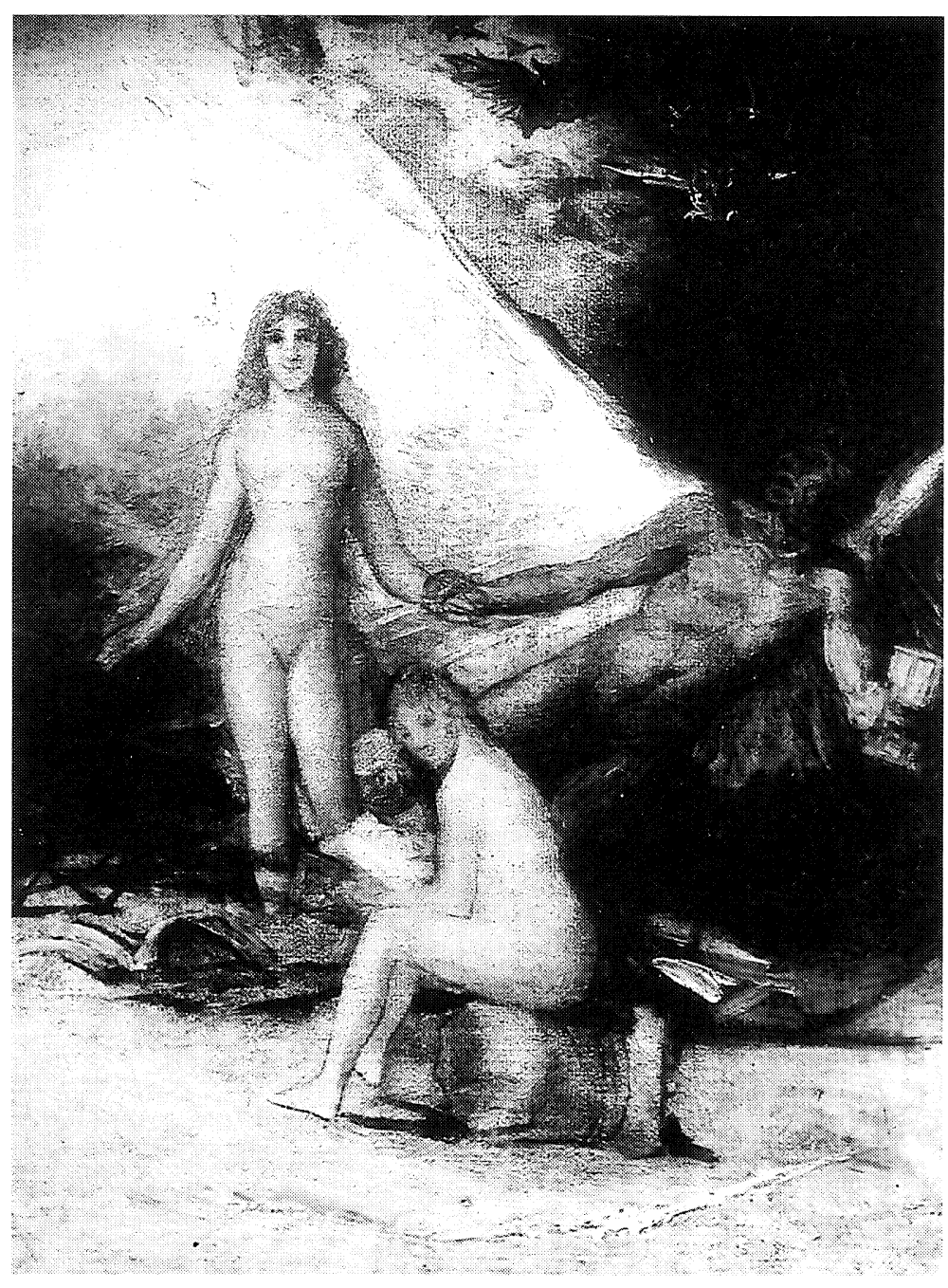

Fig. 10. Goya, Verdad Tiempo e Historia. Chicago. Art Institute 
nueva, que Goya, en nuestra opinión, debió inventar. Para ello elige una personificación femenina (tradicional para todas las encarnaciones de las virtudes y del principio de vida y fertilidad), en la que reúne características como juventud, luz, blancura y libertad; le dota de dos atributos: un cetro (símbolo de la soberanía y por ello dado tradicionalmente al rey) y un libro (Constitución). Esta figura ocupa además el lugar de la Verdad en el cuadro pequeño de Boston y en cierto modo hereda también parte de su significado.

Además de esto, hay un elemento simbólico muy importante que ha pasado hasta ahora desapercibido -que sepamos-y es el árbol que el pintor coloca detrás de la figura central femenina. Si se observa con atención, se verá que es un árbol recién cortado, su tronco está cayendo y puede verse uno de sus bordes inferiores unido aún a la tierra. Este elemento, representación de lo que muere, ocupa en el cuadro de Estocolmo el mismo lugar que ocupan, en el boceto de Boston, la oscuridad y las aves nocturnas. Así pues, ambas imágenes -oscuridad y árbol derribado- representan dos momentos del pasado, superados por la luz del presente que inaugura una nueva era.

En el boceto, la Verdad triunfa sobre la oscuridad al final de los tiempos (reloj de arena vacío en la parte superior). En el cuadro asistimos al nacimiento (reloj lleno en la parte superior) de una nueva España caracterizada por la constitución (libro en la mano) y la soberanía (cetro), que acaba con un pasado de oscurantismo e ignorancia (árbol que cae). La importancia de esta nueva etapa es subrayada por la Historia, que además separa el libro del pasado manteniéndolo bajo su pie.

En nuestra opinión, la imagen se refiere sin duda a la España constitucional de 1812 y a los principios del liberalismo, que fueron los que impusieron la soberanía nacional en la constitución de ese año (cetro que ahora no corresponde al rey ni a la monarquía en exclusiva, por lo que la figura deliberadamente carece de corona). Fueron los liberales quienes usaron en sus discursos en las Cortes de Cádiz imágenes parecidas a la pintura de Goya; por ejemplo, refiriéndose a la abolición de la propiedad vinculada, los liberales hablaron de suprimirla «arrancando de raíz el árbol que produce tan amargos frutos» ${ }^{47}$. Goya pues inventa una alegoría nueva para una situación nueva y crea la España constitucional frente a la España absolutista y monárquica, por ello los atributos del cetro y el libro no deben interpretarse, en nuestra opinión, acudiendo a la simbología de los viejos tratados de iconografía, sino viéndolos como dos elementos actuales que representan la constitución y la soberanía, ahora en poder de la nueva España. Lo mismo podríamos decir del árbol cortado, imagen habitual, tanto en la retórica como en la plástica, cuando se trata el tema de la muerte y presente por consiguiente en libros y estampas referidos a esta iconografía que Goya y su cliente conocerían, pero que creemos hay que relacionar aquí más con la actualidad contemporánea que con el código iconográfico del pasado.

Desafortunadamente no sabemos para quién se hizo esta obra ${ }^{48}$.

Por lo expuesto anteriormente pensamos que se creó en torno a la proclamación de la Constitución de 1812. Las primeras noticias que tenemos de ella son las de Yriarte en 1867, quien, además de transmitirnos el título que seguramente le fue indicado, nos dice que estaba en Cádiz, en casa del cónsul austriaco.

\footnotetext{
47 La frase es citada por Raymond Carr en España, 1808-1939, Barcelona, 1978, pág. 108. En este mismo capítulo se trata de la posición de conservadores y patriotas liberales sobre temas como la soberanía popular-defendida igualmente por los liberales- y del papel de la nación y la monarquía, temas todos ellos estrechamente relacionados con el cuadro de que tratamos y ampliamente debatidos en las cortes de Cádiz.

48 Recuérdese que la Suposición de Gudiol como hecha, junto a la Alegoría de la Poesía, para el palacio de Godoy, no se ve corroborada por las citas en el palacio del Principe de la Paz y es rechazada actualmente (véase más arriba). Como en el caso de la Alegoría de Madrid, el conocimiento de la personalidad del cliente tal vez nos ayudaría a saber el peso que éste tuvo en la invención de la alegoría.
} 
Interesa averiguar, pues, si el cuadro fue hecho para alguna personalidad liberal de Cádiz, lo que explicaría la relación de sus elementos con los temas defendidos por ellos en las cortes constitucionales y la presencia de la obra en la ciudad.

Goya mantuvo contactos con personajes de la burguesía gaditana, sobre todo a partir de las visitas a la ciudad en 1792 (con estancia prolongada por la enfermedad) y 1796 y sería preciso buscar entre los políticos liberales, que participaron en la tarea constituyente, algún personaje relacionado con Goya que pudiera ser el cliente y tal vez coinspirador de la alegoría goyesca.

A este respecto se nos ocurre recordar algunos personajes retratados por Goya y que destacaron como políticos liberales defensores de la constitución de 1812. Tales son, por ejemplo, Vargas Ponce, gaditano, diputado en las Cortes de Cádiz y desterrado a Andalucía en 1814; Ramón de Posada y Soto, cuñado de Jovellanos, presidente de la Suprema Corte de Justicia de Cádiz en 1812 y defensor de la constitución; Antonio Porcel (cuya mujer Isabel Lobo (Cobos) también fue retratada por Goya y vivió en el mismo barrio del pintor), amigo de Jovellanos y de los duques de Osuna, que marchó a Cádiz a la llegada de José I y fue elegido diputado a Cortes por Granada ${ }^{49}$, y, sobre todo, Evaristo Pérez de Castro, académico de San Fernando, defensor de la libertad de prensa en las Cortes de Cádiz en 1810, poseedor de varias obras de Goya -entre ellas tres pinturas con temas de la guerra de la independencia-, interesado por la pintura, que el mismo practicaba, y por las alegorías políticas y a quien se ha sugerido como posible inspirador de algunas obras de Goya ${ }^{50}$.

Pero además debe recordarse que durante algunos años estuvieron en Cádiz no solamente escritores y políticos afines al liberalismo, sino también gran parte de la nobleza de ideas progresistas y antigua relación con Goya, como los condes de Altamira, el duque de Híjar y sobre todo la condesaduquesa de Benavente ${ }^{51}$ y sus hijos, que tan importante papel tuvieron en estos años y en el futuro liberalismo, y cuya hija Joaquina heredó, por su matrimonio, relaciones familiares con Austria ${ }^{52}$.

El cuadro que acabamos de comentar junto con la Alegoría de Madrid, examinada anteriormente, son las dos alegorías goyescas de mayor envergadura y nos sirven para entender el uso y la disposición gue Goya presenta ante el mismo tema, en circunstancias muy distintas.

En el retrato del rey francés, Goya aborda el tema con desgana y desinterés, por lo que utiliza alegorías tradicionales para enmascarar el verdadero tema (retrato del rey). El resultado es una obra de lenguaje caduco y falta de expresión - prescindiendo naturalmente de su calidad pictórica-.

En la alegoría de la España constitucional, por el contrario, Goya aborda un tema de interés para él en aquellos momentos y con el que estará comprometido personalmente ${ }^{53}$. Como en

49 Para datos biográficos sobre Porcel y su mujer puede verse José Valverde, Madrid, "Cuatro retratos goyescos de la sociedad madrileña", AIEM, 1991, págs. 23-36.

50 Nigel Glendinning, "Arte e ilustración en el círculo de Goya», en Goya y el espíritu de la Ilustración, Madrid [1980], págs. 73-88.

51 Todos ellos aparecen en el padrón de Cádiz de 1813. Sobre la actividad política y social de la ciudad en esos años y la presencia de refugiados en la misma puede verse: Ramón Solís, El Cádiz de las Cortes. La vida en la ciudad en los años de 1810 a 1813, [Madrid], 1987.

52 Cabe recordar a este respecto que Joaquina estaba casada con el marqués de Santa Cruz, hijo de una austríaca - Mariana Waldstein retratada también por Goya en 1798- y cuya familia había ostentado la embajada de España en Viena. Sobre Mariana de Waldstein puede verse Jeannine Baticle, "Le portrait de la Marquise de Santa Cruz par Goya», Revue du Louvre, 1977, págs. 153-163.

53 Sobre la evolución de Goya desde la ideología de la Ilustración al liberalismo hay ya pocas dudas. No solamente por las noticias biográficas de los años posteriores al trienio liberal, la postura política de Leocadia Zorrilla y de su hijo, causa de su viaje precipitado a Francia, sino también por la relación de Goya con el lenguaje y las ideas expresadas en la prensa liberal, en cuyos periódicos aparecen las primeras referencias y artículos referentes a Goya y a su obra. Sobre esto puede verse especialmente José Álvarez Lopera, "De Goya, la constitución y la prensa liberal», en Goya y la constitución de 1812, ob. cit., págs. 23-51. 
otras ocasiones aprovecha una obra anterior (boceto), de alegorías sencillas y tradicionales, transformando una de ellas con elementos sacados de la realidad histórica contemporánea y creando así una alegoría nueva. El resultado es una obra dinámica en la que la juventud y luminosidad del personaje principal representan igualmente la modernidad y claridad del lenguaje alegórico inventado.

Vemos pues en estas dos obras el resumen perfecto de la postura de Goya ante la alegoría. En la primera se muestra alejado de la obra y utilizando mecánicamente un lenguaje abstracto habitualmente fuera de su interés. En la segunda se muestra comprometido y cuidadoso por expresar de una manera clara, una idea igualmente abstracta, pero cuyo significado en el momento presente tiene que ver con vivencias y sentimientos muy importantes en la vida personal y colectiva.

Sea como fuere la gestación de la alegoría en el cuadro de Estocolmo, ésta debió ser tan del agrado de Goya que tal vez volvió a utilizarla -como ha señalado Sayre también- en el retrato de Fernando VII hecho para el ayuntamiento de Santander en 1814 (fig. 8).

El cuadro consta de distintos elementos alegóricos gue fueron precisados por el Concejo al hacer el encargo: «[El rey] deberá tener la mano apoyada sobre el pedestal de una estatua de España coronada de laurel y estarán en este pedestal el cetro, corona y manto: al pie un león con cadenas rotas en las garras" 54 .

Las alegorías precisadas en el encargo -España heroica, atributos de la realeza y libertad obtenida - fueron respetadas minuciosamente por el pintor, pero la figura de España, aungue coronada de laurel, recuerda la que aparece en el cuadro de Estocolmo, con el pecho semidescubierto y los brazos extendidos de igual manera, aunque lógicamente Goya colocó las manos de forma que sólo aquellos que conocieran la obra anterior pudieran establecer claramente la relación con la España constitucional, suprimida por el rey pocos meses antes, pero presente siempre en el ánimo de Goya. Por otro lado, en el pedestal que sostiene la estatua de España aparece media cabeza de perfil, dentro de una moldura circular a la manera de las medallas antiguas. La cabeza parece de un hombre viejo, la nariz muy redondeada y fue introducida libremente por Goya, ya que no se menciona en las condiciones del encargo; sería por tanto interesante saber si Goya quiso significar algo especial con esta cabeza.

De momento lo único que sabemos, que pudiera tener relación con ello, es que en 1812 se fundió una medalla conmemorativa de la Constitución de Cádiz, en la que aparece Fernando VII de perfil y coronado de laurel, a la manera de los emperadores romanos. En ella se puede leer que el rey de las Españas es tal "por la gracia de Dios y de la Constitución». Naturalmente, la imagen que aparece en la medalla muestra a Fernando VII joven e imberbe, con su perfil característico -nariz redondeada y barbilla muy recta- y en el reverso una alegoría de España y América sosteniendo ambos mundos el libro de la constitución, sobre el que aparece una estrella refulgente 55 .

Cabría preguntarse tal vez si, teniendo en cuenta la trayectoria de Goya, el pintor quiso dar aquí una nueva cita constitucional convenientemente enmascarada dada la fecha de realización del cuadro.

Sobre estos temas relativos a la historia de España posterior a 1812 existen varios dibujos y grabados de Goya en los que el pintor inventa y expresa, a través de la alegoría, sus ideales sobre el momento histórico, utilizando imágenes que desarrollan y aclaran las ideas expresadas en el cuadro de Estocolmo.

\footnotetext{
54 Apud Goya y la constitución de 1812, ob. cit., pág. 88.

55 La medalla fue obra de Félix Sagau, realizada en 1812. Puede verse reproducida, anverso y reverso, junto a amplias referencias históricas y bibliográficas en el artículo de Javier Gimeno, "Las medallas constitucionales de 1820", Goya, 1988, págs. $62-67$.
} 
Fundamentalmente son los dibujos y grabados correspondientes al final de la serie de Los desastres de la guerra llamados también Caprichos enfáticos: Nada, Murió la Verdad, Si resucitará?, Esto es lo verdadero y a los dibujos Lux ex tenebris (Álbum C 117), Sol de justicia (C 118) Divina Razón no deges ninguno (C 122) y España constitucional asediada por espíritus malignos (álbum F 45).

Todos ellos recogen la misma asociación de la constitución con la luz, la verdad, la libertad, la justicia, la pureza y el bien, y sirven para aclarar y ampliar la alegoría pintada en el cuadro del Museo de Estocolmo. Todos ellos han sido estudiados rigurosamente en varias ocasiones, por lo que no creemos necesario ampliar esta cita y sí remitir a anteriores publicaciones ${ }^{56}$.

Durante algún tiempo se pensó que la obra relacionada en el inventario de bienes de Goya, de 1812, como E1 Tiempo (núm. 23 en 150 rs.), correspondiese al pequeño boceto de Boston con la Verdad, el Tiempo y la Historia ${ }^{57}$, pero en realidad se refiere al cuadro Qué tal? (fig. 11) del museo de Lille 58 .

Esta obra nos muestra la flexibilidad con que Goya utiliza la alegoría. La guadaña del viejo Cronos, alegoría de la muerte que siega la vida de los humanos, ha sido transformada en esta ocasión en una escoba, dispuesta a caer sobre la cabeza de la anciana que se contempla en el espejo, al parecer más con la intención de despertarla a la realidad de sus años que de cortar su vida definitivamente. La semejanza de la reina María Luisa y la presencia de la joya en forma de dardo, que identifica a la reina ${ }^{59}$, así como las palabras escritas al reverso del espejo, nos sumergen en el mundo de Los Caprichos, es decir, de la denuncia y el sarcasmo y de la alegoría de hechos reales y contemporáneos ${ }^{60}$.

Los Caprichos de 1799, y por tanto anteriores a las últimas pinturas examinadas -aunque sean citados ahora-, fueron hechos por Goya libremente y destinados a su venta pública, por tanto no dependían de las indicaciones del cliente. En ellos Goya utiliza elementos e imágenes consagrados por el lenguaje alegórico tradicional, por ejemplo alas de mariposa, orejas de burro, sirenas, harpías, sátiros, máscaras y figuras de doble rostro para expresar vicios, virtudes o características morales de las personas y los mezcla con proverbios, con personajes de fábulas de su tiempo, del teatro, y de la vida contemporánea ${ }^{61}$, todo ello al servicio de una crítica social y de un cambio de valores, que constituyen objetivos opuestos a la alegoría tradicional.

También utiliza algunas referencias mitológicas de uso popular, por ejemplo el grabado número 9 recibe el título - no la imagen- de Tántalo con el fin de evocar con el nombre del personaje clásico la idea de un trabajo ingente y destinado al fracaso, o el número 56, Subir y bajar, cuyo título e imagen evocan la rueda de la Fortuna, utilizada para expresar el poder absoluto de quien dirige el destino de los hombres caprichosamente y por tanto recuerda lo mudable de las situaciones.

56 Además del estudio de Gassier, Dibujos de Goya. Los álbumes, Barcelona, 1973, estos dibujos y grabados han figurado, entre otras, en las exposiciones de Goya y la constitución de 1812, Madrid, 1982 (con un estudio en el catálogo de Pita Andrade: "La ideología liberal en las pinturas y dibujos de Goya», págs. 71-78) y Goya y el espíritu de la Ilustración, Madrid, 1989, en cuyo catálogo los dibujos que nos interesan fueron estudiados por Michael Armstrong Roche. También es interesante al respecto Alcalá Flecha, Literatura e ideología en el arte de Goya, [Zaragoza], 1988, págs. 441 ss.

57 Sánchez Cantón, ob. cit., 1946, pág. 86.

58 Como es sabido, el cuadro lleva la marca X 23, que corresponde al número de inventario más la inicial de Xavier Goya, a quien fue adjudicada la obra (Gudiol, ob. cit., pág. 60).

59 Es la misma que muestra en la Familia de Carlos IV, Gudiol, ob. cit., pág. 63.

60 Recuérdese que esta pintura está en relación con el Capricho, núm. 55, Hasta la muerte.

61 A este respecto, la búsqueda de fuentes literarias e icónicas para las imágenes que aparecen en Los Caprichos es continua y se refleja en una amplísima bibliografía -que aquí, como es lógico, no mencionamos- que muestra la relación con emblemas, obras de teatro, fábulas, proverbios y estampas tanto populares como cultas, y antiguas como modernas. Especialmente numerosas son las referencias a fuentes emblemáticas hechas por estudiosos de Goya o de la emblemática. (Un buen resumen bibliográfico de estos estudios puede verse en José Manuel B. López Vázquez, "Posibilidades de interpretación de la obra de Goya a través de los emblemas», Cuadernos de Arte e Iconografía, 1991, págs. 141-166). 

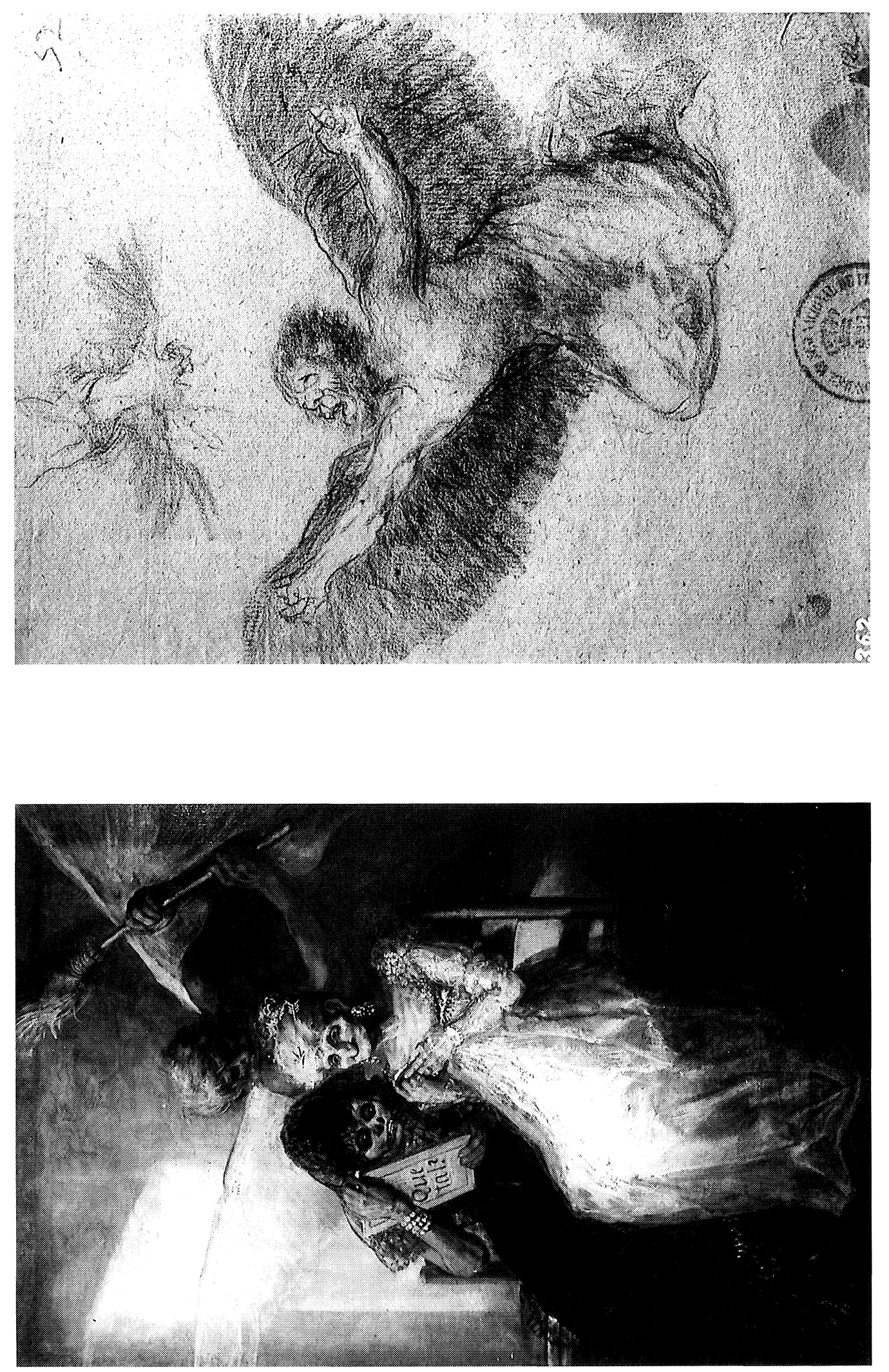

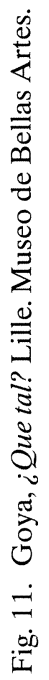


A partir de aquí se puede decir que Goya hace alegorías en el sentido de significar una cosa por otra distinta, pero en ellas el significante carecerá de un código de interpretación común y el significado de una aceptación colectiva y generalizada.

En este sentido podemos considerar también las Pinturas negras y Los Disparates como alegorías, pero serán alegorías con el lenguaje del arte moderno y, por lo mismo, cargadas de subjetividad y resistentes a la interpretación externa.

En las Pinturas negras realizadas, como es sabido, entre 1820 y 1822 , en las paredes de su casa junto al Manzanares, aparecen personajes de la mitología clásica como Saturno y las Parcas.

La imagen de Saturno, como se recordará, estaba representada en la planta baja de la casa, acompañada posiblemente de Judit, el Aquelarre, la Romería de San Isidro, Leocadia, Dos viejos comiendo y Dos frailes.

El dios griego había sido representado ya varias veces en años anteriores como alegoría del Tiempo, pero ahora aparece en una de las acciones más peculiares de su historia: devorando a su hijo.

Yriarte resume en pocas palabras: «escena de canibalismo", el realismo de la imagen y la impresión que sigue dando al contemplarla ${ }^{62}$. En realidad podemos considerar el Saturno más como antecedente de la "alegoría real» de Courbet que como consecuente de la mitología alegorizada del barroco.

La segunda imagen relacionada con la mitología, Las Parcas, aparece en la sala del primer piso, junto al Perro en la arena, el Duelo a garrotazos, La lectura, Dos mujeres y un hombre, Paseo del Santo Oficio y Asmodea.

Como se recordara, las Parcas, en el mundo clásico, eran tres: Cloto, Láquesis y Atropos, que presidían respectivamente el nacimiento, la vida y la muerte del hombre, a través de hilar, tejer y cortar la fibra de su vida.

Las Parcas de Goya expresan el poder absoluto del destino por encima de la voluntad del hombre. Este, maniatado y sin ver lo que sucede a sus espaldas, depende de las Parcas que, con aspecto de brujas, le consideran muñeco de sus prácticas y objeto de su capricho al disponer del hilo de su vida.

Tenemos aquí el uso de dos imágenes de la mitología tomadas como expresión de una experiencia humana histórica y cruel que niega los valores abstractos y trascendentes, relacionadas en cuanto a negatividad y pesimismo con el resto de las imágenes de la quinta del Manzanares. El significado primero de ellas, por separado, parece fácil de descifrar, pero consideradas en el conjunto realizado por el pintor, resultan palabras sueltas de un discurso cuyo código no poseemos.

Esto es aún más patente en los Disparates, la obra más difícil y menos estudiada de Goya. En ella aparecen también algunos personajes o elementos empleados anteriormente en el lenguaje alegórico (gigantes, máscaras, monstruos), incluso alguna de sus imágenes, por ejemplo, la número 16 (Exhortaciones), ha sido interpretada en relación con el episodio clásico de Hércules en la encrucijada ${ }^{63}$, en cuanto elección forzosa en un momento crucial de la existencia; la imagen podría recoger tal vez la verdad expresada en el mito aunque no su tradición icónica ni literaria.

Esto mismo puede apreciarse en las obras realizadas durante los últimos años de su vida.

62 Años antes, hacia 1797, Goya había realizado un dibujo sobre el mismo tema, el llamado Brujo saturniano, en el que aparece el viejo personaje devorando a uno de sus hijos mientras otro aguarda su turno. Esto indica que era un tema antiguo en el interés de Goya que ahora plasma definitivamente en las pinturas de su casa. Como ha señalado repetidamente la historiografía, en la colección real existía el famoso Saturno de Rubens (Prado), que Goya sin duda conocía, y que muestra también una imagen realista y terrible, aunque de carácter distinto. Sobre este tema y el conjunto de las pinturas negras, en relación con la melancolía, véase el estudio que realiza Nordström (ob. cit.), págs. 222-263.

63 Alfonso E. Pérez Sánchez, Goya. Caprichos-Desastres-Tauromaquia-Disparates, Madrid, 1979, pág. 173. 
Hay dibujos en los que hace surgir una imagen, cuyo texto (Pobre e gnuda vai filosofia ${ }^{64}$, E28 por ejemplo) o cuya iconografía (La guerra?, H15, por ejemplo), los relaciona con alegorías de distinto tipo. En otros aparece claramente la representación de una historia de la mitología griega (Dédalo e Ícaro, H52) (fig. 12), o se descubre a través de referencias contemporáneas que aclaran la relación de una imagen con su antecedente mitológico, como el dibujo que representa a un escultor y su obra (F90) y que ha sido estudiado por Sayre en relación con el mito de Pigmalión 65 .

En ellos Goya sigue la trayectoria iniciada en Los Caprichos, uso de imágenes o textos relacionados con el mundo clásico, pero cuyo significado no se alcanza con los códigos comunes. Es esta carga de subjetividad la que inaugura el nuevo lenguaje.

Hasta aquí hemos revisado pinturas y dibujos de tema alegórico y mitológico hechos por Goya desde el comienzo de su vida artística ${ }^{66}$. Hemos visto primeramente cómo los temas mitológico y alegórico constituyen una pequeña parte de la gran producción artística de Goya. Hay una primera etapa de juventud en la que el pintor, sin concretar aún mucho sus intereses personales, realiza obras de este tipo siguiendo las indicaciones y el gusto del cliente o del mercado, utiliza la alegoría en el sentido barroco de demostración, persuasión y glorificación de valores establecidos y heredados, recurre para ello a la fuente más empleada en el siglo xvir y más generalizada en su época, a la Iconología de Cesare Ripa, obra recomendada como manual en la enseñanza de su tiempo y utilizada en la práctica de sus contemporáneos.

Así lo hemos comprobado en numerosas obras en las que el pintor no participa internamente por no corresponder en absoluto a lo que son sus intereses, valores y vivencias personales en ese momento. De esta etapa se separan tal vez Los Temperamentos, que tocan aspectos del mundo interno en los que Goya sí estaba interesado.

El cambio, en nuestra opinión, viene claramente marcado en El Coloso y en dos pinturas: la Alegoría de Madrid, última en sentido barroco, destinada a persuadir y a glorificar según valores establecidos, y construida con un lenguaje codificado y común, y la España constitucional, destinada a mostrar, explicar y justificar unos valores modernos y minoritarios, y que por ello introduce también nuevos elementos de lenguaje extraídos de la historia contemporánea.

La última etapa sería ya la ruptura definitiva con el lenguaje alegórico anterior, al cortar toda referencia a significados trascendentes y generalizados y al renunciar a una expresión clara y racional y a un significado preciso. El uso de la alegoría en Goya pasaría así de la persuasión barroca y la precisión ilustrada al subjetivismo moderno.

\footnotetext{
${ }_{64}$ Recordamos aquí que en el inventario de los bienes de Goya de 1812 aparecía una pintura con el título de La filosofía y S. Gerónino (Sánchez Cantón, ob. cit., 1946, pág. 106), obra desconocida por ahora.

${ }^{65}$ En Goya y el espiritu de la Ilustración, ob. cit., págs. 428-431.

${ }_{66}$ Lo referente a la primera etapa puede verse en el artículo «Goya, el lenguaje alegórico y el mundo clásico. Sus primeras obras", $A E A, 1995$, pág. 165-177.
} 